\title{
The Rise and Fall of the British Nation: a Twentieth Century History
}

Review Number: 2307

Publish date: Thursday, 14 February, 2019

Author: David Edgerton

ISBN: 9781846147753

Date of Publication: 2018

Price: $£ 30.00$

Pages: 720pp.

Publisher: Allen Lane

Publisher url: https://www.penguin.co.uk/books/192782/the-rise-and-fall-of-the-british-nation/

Place of Publication: London

Reviewer: Scott Newton

For almost 30 years David Edgerton has produced a series of well-researched and ground-breaking revisionist accounts of this country's recent past, which have exposed the inadequacies and weaknesses of 'declinism' as an explanation of Britain's changing domestic and international experience since 1900. In studies such as England and the Aeroplane (1991 and 2013) and Warfare State: Britain, 1920-1970 (2005) he has convincingly shown how and why the nation remained a major power with its own formidable military-industrial complex for much of the last century.

The Rise and Fall of the British Nation takes up these arguments but goes beyond them, reaching out to social and cultural as well as military, political, economic and technological history. Edgerton seeks to explain how a British nation was constructed after 1945, emerging out of the British Empire and the global, free trade economy which had been constructed during the 19th century. By contrast, the British nation rejected imperialism and cosmopolitanism. Like most of its continental neighbours at the same time, post1945 Britain adopted industrial protectionism, encouraged agricultural self-sufficiency, and promoted growth and modernization through a developmental state. It built a National Health Service and ran 'nationalized' industries such as British Rail or British Steel. The mines were publicly owned and run by a National Coal Board. From the early 1960s this post-imperial nation, initially concerned to protect its interests in the world via a large and powerful military, complete with state-of-the-art aircraft and an independent nuclear deterrent, reduced its defence budget and increased investment in welfare and education. By the 1970s it had become a social-democratic state.

This new, specifically British nation was, however, destroyed by Thatcherism after 1979. Thatcherism latched onto the numerous declinist Jeremiads concerning post-war Britain, many written by influential intellectuals, journalists and politicians who argued that the country was losing its power and influence in the world thanks to slow growth, an uneasy relationship with modern technology, distrust of scientists and experts, and an industrial sector suffering from lack of investment and outdated practices. These critiques were made on both sides of the political spectrum. Bennites (identified here not as socialists but as 'leftnationalists'), social democrats and socialists argued for varieties of a more dirigiste State to take a strategic role in the modernization of industry. On the other hand, from the right came calls for a large dose of free 
market medicine and the opening of the economy to the forces of international competition. State support for and ownership of industry would be drastically curtailed and the power of the unions restricted by legal sanction.

Edgerton rightly points out that these critiques were based on a series of false assumptions. In a highly impressive and striking series of well-documented and authoritative chapters he shows that Britain had modernized in the decades after 1945: it had a very productive agricultural sector, a new road network (the motorway system, most of which was constructed between 1958 and 1988), an efficient power generation and distribution system based initially on its coal resources but, increasingly, also on State-owned nuclear power and gas industries, and a successful high-tech sector where computing and aerospace were especially successful at home and in overseas competition. Scientists and experts played key roles in developing new industrial processes and running advanced technical industries such as the Atomic Energy Commission. Between 300,000 and 400,000 houses were built each year for most of the time from the 1950s until the 1970s. From the early 1960s at the latest there was large-scale investment in schools, universities and hospitals. The nation's growth rate was high by the standards of its own history, there was full employment and declining inequality; living standards, especially those of the working class and the middle class, rose steadily.

Nevertheless, the Thatcherite critique prevailed and the rather successful British nation was dismantled in the decades after 1979. It became increasingly internationalized. By the early 21 st century Britain was a global, free market society characterised by growing inequality. Its leading national companies and publicly owned industries were sold off and, along with a large part of its publicly owned housing stock, often ended up in the hands of foreign owners; the London Stock Exchange was dominated after 1986 by overseas businesses, many in the USA; unemployment rose to levels which in the early post-war decades would have been regarded as scandalous as large parts of British manufacturing were allowed to collapse; workers' rights were eroded or destroyed in the name of competitiveness; significant parts of the health and social care system were handed over to 'providers' located abroad; universities became 'vast enterprises and property portfolios'; even sport was affected, as leading football clubs were taken over by foreign millionaires, some turning into global brands.

Margaret Thatcher had made it her aim to reverse Britain's mythical decline by stimulating the entrepreneurial energies of its people. Edgerton finds little evidence that she succeeded, pointing to the examples of Richard Branson ('a brand' who no longer owns many of the firms using his name); Sir James Dyson, who relocated his manufacturing business from Malmesbury to Malaysia and Singapore (retaining only the firm's research and development facility in Britain); and Sir Alan Sugar, once a serious force in the UK computing industry but now running what is mainly an extensive property portfolio (and, it might be added, fronting a television programme which is more self-parody than the entertaining guide to the role of innovation and management in business it purports to be). Average per annum growth was below the level achieved between 1945 and 1979.

Notwithstanding this unimpressive record, no challenge to the new, post-national Britain was made by Labour. When it returned to power as 'New Labour' in 1997, after 18 years in opposition, it did not attempt to alter the fundamentals of Thatcher's Britain. Indeed it built on her legacy, continuing to promote a significant role for the private sector in the delivery of public services, even when, as with the Private Finance Initiative, this proved to be a very bad deal for the taxpayer. Its economic strategy revolved around fantasies such as 'Cool Britannia' and the 'knowledge economy'. Blair continued with Thatcher's strong Atlanticism and was a willing participant in and cheerleader for George W. Bush's disastrous Iraq War. Power was all to New Labour; the Party, in its new guise, abandoned its tradition of criticising capitalism and embraced the system. The very idea of opposition disappeared from British politics, where better management of the existing order was seen as the path to success. Edgerton concludes his study with a snapshot of Britain on Thatcher's death in 2013: the 'iron lady' being granted 'an all-but-state funeral', complete with gun carriage, procession and military honours. As this proceeded, 'forgotten former miners celebrated bitterly' in 'the old and distressed pit villages' of England, Scotland and Wales. Meanwhile Tony 
Blair was making money 'working for some of the vilest torturers and dictators on earth'. Edgerton concludes his book with the melancholy observation that 'only satirists could do justice to this turn of events'.

This is, overall, a very fine book. Its argument, well supported by a wide range of material and much learning, makes for a new and persuasive interpretation of British history since 1900. Its account of post-war British modernization, discussion of the central but often ignored role played by intellectuals, grasp of how Thatcherism in effect dismantled and then internationalized what had been a distinctive social democratic nation, and concluding discussion of New Labour are particular strengths. It is written with learning and, at times, with some passion; and is shot through with humanity.

There are, however, some areas where Edgerton's grasp is not so secure. First, in his discussion of imperial Britain he criticises the work of Peter Cain and Tony Hopkins for overplaying 'the role of pure finance', arguing that British overseas interests were 'commercial and industrial' as well as financial and rentier.[1] [2] 'The City', he says, 'was as much about commodities as money'. This is to attack a straw man. Cain and Hopkins see the overseas lobby as a complex, composed of economic interests not all of whom were financiers. Many were owners of shipping companies and firms building railways, ports and roads. There were exporters of Chilean nitrates, tea planters in India, owners of Brazilian coffee plantations and farmers of Argentinian beef and of grain from the prairies, for example. What linked all these interests together was their connection to the City: London banks and financiers provided insurance and credits for trade and the vast resources of capital which allowed Britain to pull one region of the globe after another into the world market. Britain itself was an externally oriented economy; in J. A. Hobson's words, finance was 'the governor ... of the imperial engine' but it was not the engine itself, and this is a distinction Cain and Hopkins appreciate.

Secondly, although Edgerton is right to stress the continuity between the 1930s and 1940s in welfare policy, he does underplay the differences between the two eras. One great change of the 1940s was that everyone could see the doctor and be prescribed medicine without having to pay: 'free at the point of need' was a profound improvement to many, especially women who had not been covered by pre-war insurance schemes. Another was the removal of the humiliating petty cruelties of the means test, which was greeted with relief by many working-class families who had experienced them prior to the war (my own being a case in point).

Thirdly, Edgerton's characterizes post-war Britain as economically nationalist and social democratic. Yet social democracy was in fact nationalist from the start, by its nature. It grew out of the need of Parliamentary socialist parties to win elections. To do this, they needed to be accountable to national electorates and above all to the working-class communities whose interests they had been created to represent and defend back in the 1890s. In practically all the countries where these movements were strong they built coalitions with middle-class professional groups sympathetic to social reform and the redistribution of wealth away from landlords, industrialists and financiers. In consequence, left-of-centre parties across Western Europe (including, of course, the UK) developed political programmes which aimed, successfully (after 1945 in particular) to deliver various versions of welfare states, full employment and the public ownership of major industries and banks. The need to prevent this new social order being disrupted by market forces, promote modernization of key economic sectors and preserve jobs at the same time led governments to adopt protectionist measures - import quotas, tariffs, investment in new technology and in firms deemed to be at the cutting edge of development. All this was seen as essential to the maintenance of national economic growth and the creation of the wealth which socialist and social democratic parties could redistribute to the interests which had created them and which continued to fund and support them.[2] [3]

Yet politics was not just about winning votes: it was also about building a fairer society, a more just social and economic order, a New Jerusalem as it was sometimes called. What else but the nation state had the power and resources and political institutions capable of building this new world? Despite the pioneering work of Alan Milward in a series of seminal texts over a period of two decades[3] [4], it is still not widely appreciated that the material roots of the European Economic Community were to be found in the 
determination of the six nation states creating it to build an external economic environment congenial to continuation of the growth and full employment generated by developmental and dirigiste post-1945 reconstruction policies. High-sounding aspirations to international co-operation were good rhetoric but if the urge to European co-operation had been based on those alone it would soon have collapsed, as it did between the wars. Things were different after 1945 because western democracies all experienced a decisive shift in the balance of social forces in favour of the working class and its representative institutions - trade unions and political parties committed to social-democratic programmes. Britain was no exception to this process.

Finally, the discussion of what Thatcherism was about and what it achieved is excellent; but the explanation of why this counter-revolution took off is rather sketchy. Edgerton writes of a 'rulers' revolt' against the postwar order and identifies very accurately what this uprising was against - powerful unions, 'too much Government', apparent hostility to private enterprise, too few producers of wealth and too many drains on the taxpayer from social security claimants, nationalised industries and failing companies. Edgerton says that '[s]ometime in the 1970s a chunk of the upper class said enough is enough', and, supported by a significant fraction of the middle class, set about taking the social democratic order apart, replacing it with one driven by the principles of the free market. This is undeniable as far as it goes but doesn't cut it as an explanation. After all, as Edgerton point out, most of the targets of this 'rulers' revolt' existed only in the insurgents' fevered imaginings. Late 1970s Britain was a country where unemployment and inflation were falling, the external balance was in surplus, the economy was growing at a very respectable rate, and living standards were rising.

What, then, does explain this 'rulers' revolt'? We need to invoke a term Edgerton (like, I suspect many British contemporary historians) dislikes: neoliberalism. This concept is unpopular, perhaps because it cannot be empirically tested and proved; perhaps because it has been bandied about rather too casually: does it describe 'a theory, a set of ideas, a political strategy or a historical period?' [4] [5] There is an answer to this question, a definition of the term providing us with an analytical tool which helps to make sense of what happened. Neoliberalism is 'a political project carried out by the corporate capitalist class as they felt intensely threatened both politically and economically towards the end of the 1960s into the 1970s. They desperately wanted to launch a political project that would curb the power of labor'[5] [6] and did so in response to a series of perceived threats to capitalism observed across the globe, not just in the UK: working class militancy, powerful Leftist parties in western Europe and parts of Latin America, and revolutionary governments taking power in former colonies such as Mozambique and Angola.

Thatcherism was central to this project. It aimed to make free market capitalism the dominant form of the system. Thatcherites regarded the post-1945 variant, dubbed 'welfare capitalism' in much of the developed world, as a socialist Trojan Horse. Interestingly, there are parallels with Marx here. Writing in the 1870s and 1880s he suggested in Capital volume three that capitalism had started to evolve into a system of 'associated production' thanks to the centralisation of credit and the rise of the joint-stock company, in which corporations controlled by managers and workers would replace those run by their owners, now being transformed into numerous inactive shareholders. The potential would be there for a transition to production on a co-operative basis gradually to become generalised throughout the global economy.[6] [7]

Marx may have been a tad premature, but the process was very obvious by the 1930s and 1940s. For much of the Left in the developed world after the mid-1950s it became key to the construction of a revisionist socialism. Wholesale replacement of private ownership of the means of production by public ownership, a longstanding aspiration of socialist parties, was now believed unnecessary. The traditional objective of greater social equality could be delivered by mixed economies, progressive taxation, high levels of spending on health, education and welfare and by the formulation of industrial and economic strategy via co-operation between the State, the unions and the employers. And indeed, these were the policies promoted by Labour administrations in the UK and by socialist and social democratic governments throughout Western Europe during the 1960s and 1970s. They did not involve direct confrontation with capitalism but still provoked anxiety on the Right that the free enterprise system was now facing an existential crisis. The necessary, if not sufficient, condition for overcoming this crisis was a strategy to weaken and undermine organised labour, the 
social basis of the Left. Thatcherism was the political expression of that strategy; it was the project launched by capital to curb the power of labour. Neoliberalism, then, enables us to understand the meaning and the point of Thatcherism, while locating it in a specific historical period, opening about 50 years ago and still unfolding.

These are genuine criticisms of the book but they do not detract from its very considerable quality. There can be no doubt whatever that Edgerton has performed a great service not just for professional historians working in the Academy but for all thinking people who are concerned with the business of History in general and Britain's own story in particular. He has produced a powerful and compelling, at times magisterial and masterly text. We can only hope that The Rise and Fall of the British Nation will be the inspiration for many others keen to follow up the ideas and leads in his work with their own accounts.

[1] [8] The key text is P. J. Cain and A. G. Hopkins, British Imperialism, 1688-2015, 3rd edition (London, 2016).

[2] [9] See for example David Thomson, Europe Since Napoleon (London, 1966), pp. 425-7; and Scott Newton, The Reinvention of Britain: a Political and Economic History (London, 2017).

[3] [10] For example, A. S. Milward, The Reconstruction of Western Europe, 1945-51 (London, 1984); and The European Rescue of the Nation-State, 2nd edition (London, 2000).

[4] [11] 'Neoliberalism is a Political Project', interview with David Harvey, Jacobin (23 July 2016) < https://www.jacobinmag.com/2016/07/david-harvey-neoliberalism-capitalism... [12] [accessed 2 January 2019].

[5] [13]Harvey's A Brief History of Neoliberalism: (Oxford, 2005) is an invaluable introduction to the subject.

[6] [14] Karl Marx, Capital: Volume III (London, 1991), ch. 27, pp. 566-74.

\section{Other reviews:}

Guardian

https://www.theguardian.com/books/2018/jun/16/the-rise-and-fall-of-the-british-nation-and-these-islandsreview [15]

Spectator

https://www.spectator.co.uk/2018/07/historian-david-edgerton-says-the-british-nation-lasted-from-1945-to1979-the-miners-strike-its-death-knell/ [16]

Times Literary Supplement https://www.the-tls.co.uk/articles/public/review-david-edgerton-british-nation/ [17]

Evening Standard

https://www.standard.co.uk/lifestyle/books/the-rise-and-fall-of-the-british-nation-a-twentieth-centuryhistory-by-david-edgerton-review-a3868486.html [18]

Herald

https://www.heraldscotland.com/arts_ents/16250533.review-the-rise-and-fall-of-the-british-nation-atwentieth-century-history-by-david-edgerton/ [19]

Source URL:https://reviews.history.ac.uk/review/2307

\section{Links}

[1] https://reviews.history.ac.uk/item/298693 
[2] https://uolonline-

my.sharepoint.com/personal/danny_millum_sas_ac_uk/Documents/Reviews/current\%20reviews\%20for\%20editing/r [3] https://uolonline-

my.sharepoint.com/personal/danny_millum_sas_ac_uk/Documents/Reviews/current\%20reviews\%20for\%20editing/ [4] https://uolonline-

my.sharepoint.com/personal/danny_millum_sas_ac_uk/Documents/Reviews/current\%20reviews\%20for\%20editing/r

[5] https://uolonline-

my.sharepoint.com/personal/danny_millum_sas_ac_uk/Documents/Reviews/current\%20reviews\%20for\%20editing/r [6] https://uolonline-

my.sharepoint.com/personal/danny_millum_sas_ac_uk/Documents/Reviews/current\%20reviews\%20for\%20editing/r [7] https://uolonline-

my.sharepoint.com/personal/danny_millum_sas_ac_uk/Documents/Reviews/current\%20reviews\%20for\%20editing/r

[8] https://uolonline-

my.sharepoint.com/personal/danny_millum_sas_ac_uk/Documents/Reviews/current\%20reviews\%20for\%20editing/r [9] https://uolonline-

my.sharepoint.com/personal/danny_millum_sas_ac_uk/Documents/Reviews/current\%20reviews\%20for\%20editing/ [10] https://uolonline-

my.sharepoint.com/personal/danny_millum_sas_ac_uk/Documents/Reviews/current\%20reviews\%20for\%20editing/

[11] https://uolonline-

my.sharepoint.com/personal/danny_millum_sas_ac_uk/Documents/Reviews/current\%20reviews\%20for\%20editing/ [12] https://www.jacobinmag.com/2016/07/david-harvey-neoliberalism-capitalism-labor-crisis-

resistance/\&gt;

[13] https://uolonline-

my.sharepoint.com/personal/danny_millum_sas_ac_uk/Documents/Reviews/current\%20reviews\%20for\%20editing/

[14] https://uolonline-

my.sharepoint.com/personal/danny_millum_sas_ac_uk/Documents/Reviews/current\%20reviews\%20for\%20editing/ [15] https://www.theguardian.com/books/2018/jun/16/the-rise-and-fall-of-the-british-nation-and-theseislands-review [16] https://www.spectator.co.uk/2018/07/historian-david-edgerton-says-the-british-nationlasted-from-1945-to-1979-the-miners-strike-its-death-knell/ [17] https://www.the-

tls.co.uk/articles/public/review-david-edgerton-british-nation/ [18]

https://www.standard.co.uk/lifestyle/books/the-rise-and-fall-of-the-british-nation-a-twentieth-centuryhistory-by-david-edgerton-review-a3868486.html

[19] https://www.heraldscotland.com/arts_ents/16250533.review-the-rise-and-fall-of-the-british-nation-atwentieth-century-history-by-david-edgerton/ 